\title{
Calcium content and high calcium adaptation of plants in karst areas of southwestern Hunan, China
}

\author{
Xiaocong Wei ${ }^{1}$, Xiangwen Deng ${ }^{1,2}$, Wenhua Xiang ${ }^{1,2}$, Pifeng Lei ${ }^{1,2}$, Shuai Ouyang ${ }^{1,2}$, Hongfang Wen ${ }^{1}$, and \\ Liang Chen ${ }^{1,2}$ \\ ${ }^{1}$ Faculty of Life Science and Technology, Central South University of Forestry and Technology, \\ Changsha 410004, Hunan Province, China \\ ${ }^{2}$ Huitong National Field Station for Scientific Observation and Research of Chinese Fir Plantation Ecosystem in Hunan \\ Province, Huitong 438107, China
}

Correspondence: Xiangwen Deng (dxwfree@126.com)

Received: 26 September 2017 - Discussion started: 23 November 2017

Revised: 22 April 2018 - Accepted: 25 April 2018 - Published: 17 May 2018

\begin{abstract}
Rocky desertification is a major ecological problem of land degradation in karst areas. In these areas, the high soil calcium $(\mathrm{Ca})$ content has become an important environmental factor that can affect the restoration of vegetation. Consequently, the screening of plant species that can adapt to high $\mathrm{Ca}$ soil environments is a critical step in vegetation restoration. In this study, three grades of rocky desertification sample areas were selected in karst areas of southwestern Hunan, China (LRD: light rocky desertification; MRD: moderate rocky desertification; and IRD: intense rocky desertification). Each grade of these sample areas had three sample plots in different slope positions, each of which had four small quadrats (one in rocky-side areas, three in nonrocky-side areas). We measured the Ca content of leaves, branches, and roots from 41 plant species, as well as soil total $\mathrm{Ca}(\mathrm{TCa})$ and exchangeable $\mathrm{Ca}(\mathrm{ECa})$ at depths of 0 $15,15-30$, and $30-45 \mathrm{~cm}$ in each small quadrat. The results showed that the soil $\mathrm{Ca}^{2+}$ content in rocky-side areas was significantly higher than that in non-rocky-side areas $(p<0.05)$. The mean soil TCa and ECa content increased gradually along with the grade of rocky desertification, in the order IRD $>$ MRD $>$ LRD. For all plant functional groups, the plant $\mathrm{Ca}$ content of aboveground parts was significantly higher than that of the belowground parts $(p<0.05)$. The soil ECa content had significant effects on plant $\mathrm{Ca}$ content of the belowground parts but had no significant effects on plant $\mathrm{Ca}$ content of the aboveground parts. Of the 41 plant species that were sampled, 17 were found to be dominant (important value $>1$ ). The differences in $\mathrm{Ca}^{2+}$ content be-
\end{abstract}

tween the aboveground and belowground parts of the 17 dominant species were calculated, and their correlations with soil ECa content were analyzed. The results showed that these 17 species can be divided into three categories: $\mathrm{Ca}$ indifferent plants, high-Ca plants, and low-Ca plants. These findings provide a vital theoretical basis and practical guide for vegetation restoration and ecosystem reconstruction in rocky desertification areas.

\section{Introduction}

Karst is a calcium-rich environment and a unique ecological system. This type of ecosystem is widely distributed, accounting for $12 \%$ of the world's total land area (Zeng et al., 2007; Zhou et al., 2009; Luo et al., 2012). Karst landforms in $\mathrm{China}$ are mainly distributed in southwestern areas. The $\mathrm{Hu}$ nan Province of China has been ranked fourth in the severity degree of rocky desertification (Li et al., 2016). Rocky desertification could lead to frequent natural disasters, reduce human survival and development space, threaten local people's production, life and life safety, cause ecological deterioration, reduce arable land resources, aggravate poverty, and affect sustainable economic and social development (Jing et al., 2016). In other words, rocky desertification is an extreme form of land degradation in karst areas, and has become a major social problem in terms of China's economic and social development (Sheng et al., 2015). Soil with high calcium $(\mathrm{Ca})$ content in rock desertification areas has become 
one of the most important environmental factors affecting the local plant physiological characteristics and distribution in these areas (Ji et al., 2009). Given the origin of rocky desertification, the main factors that lead to rocky desertification stem from unreasonable human activities. For example, the cultivation of crops on steep slopes can cause vegetation destruction, soil erosion, and then rocky desertification. We should therefore focus on vegetation restoration for rocky desertification remediation (Wang et al., 2004). Consequently, the screening of plant species that can grow successfully in high-Ca environments in rocky desertification areas is an extremely critical step.

Role of $\mathrm{Ca}^{2+}$ in plant physiology: over recent decades, progress has been made in identifying the cellular compartments (e.g., endoplasmic reticulum, chloroplasts and mitochondria) that regulate $\mathrm{Ca}$ balance and signal transduction in plants (Müller et al., 2015). $\mathrm{Ca}^{2+}$ is an essential nutrient for plant growth and also participates in signal transduction (Poovaiah and Reddy, 1993; Hepler, 2005; Hong-Bo and Ming, 2008; Batistič and Kudla, 2012). $\mathrm{Ca}^{2+}$ is also a very important signal component in plants responsive to environmental stresses. The $\mathrm{Ca}^{2+}$ signal takes the influential role as a second messenger in hormone signal transduction, particularly in the abscisic acid signal transduction process (Hetherington et al, 2004). Plants can therefore adapt to high salt, drought and high temperature environments by activating the $\mathrm{Ca}^{2+}$ signal transduction pathway (Bressan et al., 1998). $\mathrm{Ca}^{2+}$ is also involved in nutrient cycling coupling process, for example, in the absence of nutrients (such as phosphorus), plants will inhibit the activity of nitrate reductase, thereby inhibiting the absorption of nitrate nitrogen, and ultimately inhibiting the absorption of $\mathrm{Ca}^{2+}$ (Reuveni et al., 2000). Calcium ions combine with pectin in the cell walls of plants to form pectin $\mathrm{Ca}$, which is a vital component of the intercellular layer in cell walls, and can buffer the compression between cells without hindering the expansion of cell surface area (Kinzel, 1989). Ca also has the function of maintaining the structure and function of cell membranes, regulating the activity of biological enzymes, and maintaining the anioncation balance in vacuoles (Marschner, 2011).

Mechanisms of plant defense to high soil $\mathrm{Ca}^{2+}$ concentrations: $\mathrm{Ca}^{2+}$ is an essential macronutrient, but low $\mathrm{Ca}^{2+}$ concentrations must be maintained within the plant cytoplasm to avoid toxicity (Larkindale and Knight, 2002; Borer et al., 2012). The plant cell not only rapidly increases the free $\mathrm{Ca}^{2+}$ concentration of the cytoplasm to adapt to environmental changes, but also maintains a low $\mathrm{Ca}$ concentration to prevent harm caused by high $\mathrm{Ca}$. This fine regulatory mechanism is mainly achieved by $\mathrm{Ca}^{2+}$ channels (Shang et al., 2003; Hetherington and Brownlee, 2004; Wang et al., 2005). The vacuoles may account for $95 \%$ of the plant cell volume and are able to store $\mathrm{Ca}^{2+}$ within the cell. Thus, empty vacuoles represent an efficient means of $\mathrm{Ca}$ storage (Ranjev et al., 1993). Some plants fix excess $\mathrm{Ca}^{2+}$ by forming calcified deposits in root tissue in order to limit the upward transport of $\mathrm{Ca}^{2+}$ (Musetti and Favali, 2003). In addition, $\mathrm{Ca}$ oxalate crystals in the plant cells play a role in regulating plant $\mathrm{Ca}$ content (Ilarslan et al., 2001; Pennisi and McConnell, 2001; Volk et al., 2002), and some plants will form $\mathrm{Ca}$ oxalate crystal cells in order to fix excess $\mathrm{Ca}^{2+}$ (Moore et al., 2002). Furthermore, an active Ca efflux system plays an important role in the adaptation of plants to high-Ca environments (Bose et al., 2011). For example, when leaves mature, excess $\mathrm{Ca}^{2+}$ in plants is excreted via stomata on the back of the leaves, thereby maintaining a lower concentration of leaf $\mathrm{Ca}$ (Musetti and Favali, 2003). The regulation of internal $\mathrm{Ca}$ storage depends predominantly on plasma membrane $\mathrm{Ca}$ transport and intracellular $\mathrm{Ca}$ storage; collectively these processes can regulate the intracellular $\mathrm{Ca}^{2+}$ concentration to a lower level (Bowler and Fluhr, 2000). Plants that adapt to high-Ca environments promote excess $\mathrm{Ca}^{2+}$ flow through the cytoplasm or store $\mathrm{Ca}^{2+}$ in vacuoles via the cytoplasmic $\mathrm{Ca}^{2+}$ outflow and influx system (Shang et al., 2003; Hetherington and Brownlee, 2004; Wang et al., 2006). This system consists of $\mathrm{Ca}^{2+}$ channels, $\mathrm{Ca}^{2+}$ pump and $\mathrm{Ca}^{2+} / \mathrm{H}^{+}$reverse conveyor on tonoplast; the former controls $\mathrm{Ca}^{2+}$ outflow, and the latter two pump cytoplasmic $\mathrm{Ca}^{2+}$ into vacuole (Wu, 2008). Cytoplasmic $\mathrm{Ca}^{2+}$ is mainly combined with proteins and other macromolecules. The concentration of free $\mathrm{Ca}^{2+}$ is generally only $20-200 \mathrm{nmol} \mathrm{L}^{-1}$ and is stored in cell gaps and organelles such as vacuoles, endoplasmic reticulum, mitochondria, and chloroplasts (Wu, 2008). However, excess free $\mathrm{Ca}^{2+}$ in the cytoplasm combines with phosphate to form a precipitate, which interferes with the physiological processes associated with the phosphorus metabolism, thus hindering normal signal transduction and causing significant detriment to plant growth (White and Broadley, 2003; Hirschi, 2004).

Variation of $\mathrm{Ca}^{2+}$ content in species and soil: The concentration of free $\mathrm{Ca}^{2+}$ in vacuoles varies with plant species, cell type, and environment, which may also affect the release of $\mathrm{Ca}^{2+}$ in vacuoles (Peiter, 2011). Some species maintain low calcium content in their aboveground portion by reducing calcium uptake and transporting it from underground parts to aboveground parts. Examples of these types of plants are Nephrolepis auriculata, Parathelypteris glanduligera, Cyrtomium fortunei, Pteris vittata, and so on. In contrast, other plants have a higher demand for calcium, for example, Cayratia japonica and Corchoropsis tomentosa maintain high calcium content by enhancing calcium uptake and transporting it from underground sections to aboveground sections (Ji et al., 2009). Zhang (2005) studied the growth conditions of Eurycorymbus cavaleriei and Rhododendron decorum under different concentrations of $\mathrm{Ca}^{2+}$ and found that a high $\mathrm{Ca}^{2+}$ concentration $\left(50 \mathrm{mmol} \mathrm{L}^{-1}\right)$ could promote growth in Eurycorymbus cavaleriei but inhibit growth in Rhododendron decorum. Luo et al. (2013) showed that $\mathrm{Ca}^{2+}$ concentrations affected plant photosynthesis. When the daily net photosynthetic rate of Cyrtogonellum Ching and Diplazium pinfaense Ching reached the highest 
value, the concentrations of $\mathrm{Ca}^{2+}$ were 30 and $4 \mathrm{mmol} \mathrm{L}^{-1}$, respectively. Qi et al. (2013) found a significant difference in calcium content among Primulina species ( $P$. linearifolia, $P$. medica, $P$. swinglei, $P$. verecunda, $P$. obtusidentata, $P$. heterotricha, and so on) from different soil types, and that the average Ca content (2285.6 $\mathrm{mg} \mathrm{kg}^{-1}$ ) in Primulina from calcareous soil was higher than the average $\mathrm{Ca}$ content of Primulina from both acid soil (1379.3 $\mathrm{mg} \mathrm{kg}^{-1}$ ) and Danxia red soil $\left(1329.1 \mathrm{mg} \mathrm{kg}^{-1}\right)$. The mean soil exchangeable $\mathrm{Ca}$ (ECa) was $3.61 \mathrm{~g} \mathrm{~kg}^{-1}$ in the Puding, Huajing, Libo, and Luodian counties of Guizhou Province, which is several times that of non-limestone areas in China (Ji et al., 2009). Wang et al. (2011) found that plant rhizosphere soil total Ca (TCa) content in calcareous soil areas was above $14.0 \mathrm{mg} \mathrm{g}^{-1}$.

There are variations in soil $\mathrm{Ca}$ content among different areas, and there are differences between calcareous and noncalcareous plants in terms of Ca absorption, transport, storage, and other physiological processes. These differences need to be taken into account in order to identify the variety of plants able to adapt to high Ca environments. However, to date, the mechanisms by which plants adapt to high $\mathrm{Ca}$ conditions, particularly in karst areas, and the $\mathrm{Ca}$ dynamics of plants and soil are not well understood. In this study, we investigated plant $\mathrm{Ca}$ content, soil exchangeable $\mathrm{Ca}$ (ECa), and total $\mathrm{Ca}$ (TCa) contents on the rocky and nonrocky sides of three different grades of rocky desertification areas in southwestern China. Specifically, we hypothesized that the dynamics of $\mathrm{Ca}$ content in plants and soil would be significantly affected by the grade of rocky desertification. To test this hypothesis, the following investigations were undertaken: (i) to measure the soil ECa and TCa contents in rockyside and non-rocky-side areas; (ii) to investigate and compare the $\mathrm{Ca}$ content of aboveground and belowground parts of plants from different functional groups; and (iii) to reveal correlation between plant $\mathrm{Ca}$ content and soil ECa content.

\section{Materials and methods}

\subsection{Site description}

The study site was located in Lijiaping town in Shaoyang County, Hunan Province, China (latitude $27^{\circ} 0^{\prime} \mathrm{N}$; longitude $113^{\circ} 36^{\prime} \mathrm{E}$; elevation $400-585 \mathrm{~m}$ a.s.1.), as shown in Fig. 1. This region experiences a humid mid-subtropical monsoon climate. Mean annual air temperature is $16.9^{\circ} \mathrm{C}$, and maximum and minimum temperatures are 41.0 and $-10.1^{\circ} \mathrm{C}$, respectively. Mean annual precipitation is $1399 \mathrm{~mm}$, mostly occurring between April and August, and the frost-free period is 288 days. The study site mainly consists of black and yellow limestone soil, and vegetation is scarce. The groundwater level is low and groundwater storage is poor.

\subsection{Experimental design and data collection}

Rocky desertification was graded by using the sum of four index scores: bedrock exposure rate, vegetation type, vegetation coverage, and soil thickness. These index were quantified according to the State Forestry Administration of the People's Republic of China industrial standard "LY/T 1840-2009" (China, 2009). Three $1 \mathrm{hm}^{2}$ sample areas were selected which were representative of the three different grades of rocky desertification: light rocky desertification (LRD); moderate rocky desertification (MRD); and intense rocky desertification (IRD; see Table 1). Within each sample area, we recorded environmental factors which included longitude, latitude, altitude, topography, vegetation type, degree of bare bedrock, and other conditions. The collection of samples in these three sample areas was conducted in October 2016.

Within each of the three sample areas, four $(2 \times 2)$ small quadrats in different slope positions (upper, middle, and lower slope) were set up. In total, we assigned 36 small quadrats $(3 \times 4 \times 3)$ for analysis. The common plant species of the region were gathered using the whole plant harvest method in each small quadrat; shrubs and herbs were also collected. Shrubs were divided into three parts: branches, leaves, and roots. Herbs were divided into two parts: aboveground and belowground. Plant samples were taken back to the laboratory, rinsed with distilled water before being oven dried at $105^{\circ} \mathrm{C}$ for $15 \mathrm{~min}$ to de-enzyme, and then dried to a constant weight at $80^{\circ} \mathrm{C}$ about $480 \mathrm{~min}$, crushed and passed through a $0.149 \mathrm{~mm}$ sieve for chemical analysis at a later date. For the soil samples, we measured the soil TCa and ECa content of each quadrat (top soil: $0-15 \mathrm{~cm}$; middle soil: $15-$ $30 \mathrm{~cm}$; bottom soil, 30-45 cm). Soil TCa, ECa content and plant $\mathrm{Ca}$ content were measured using an atomic absorption spectrophotometer (3510, Shanghai, China).

\subsection{Data analysis}

All plant species were divided into different functional groups: (1) nitrogen-fixing plant and non-nitrogen-fixing plant groups according to nitrogen-fixing function; (2) dicotyledons and monocotyledons groups according to system development type; (3) C3 and C4 plant groups according to photosynthetic pathway; and (4) deciduous shrubs, evergreen shrubs, annual herbs, and perennial herbs according to life form. Biennial herbs were gathered to the "annual herbs" and deciduous trees with a height less than $2 \mathrm{~m}$ or a ground diameter less than $3 \mathrm{~cm}$ were gathered to the "deciduous shrubs". Branches and leaves were treated together as the aboveground part, while the belowground section only included roots. We calculated the important values (IV) via the following formula:

$\mathrm{IV}=\frac{\text { Relative Density }+ \text { Relative Height }+ \text { Relative Coverage }}{3}$ 


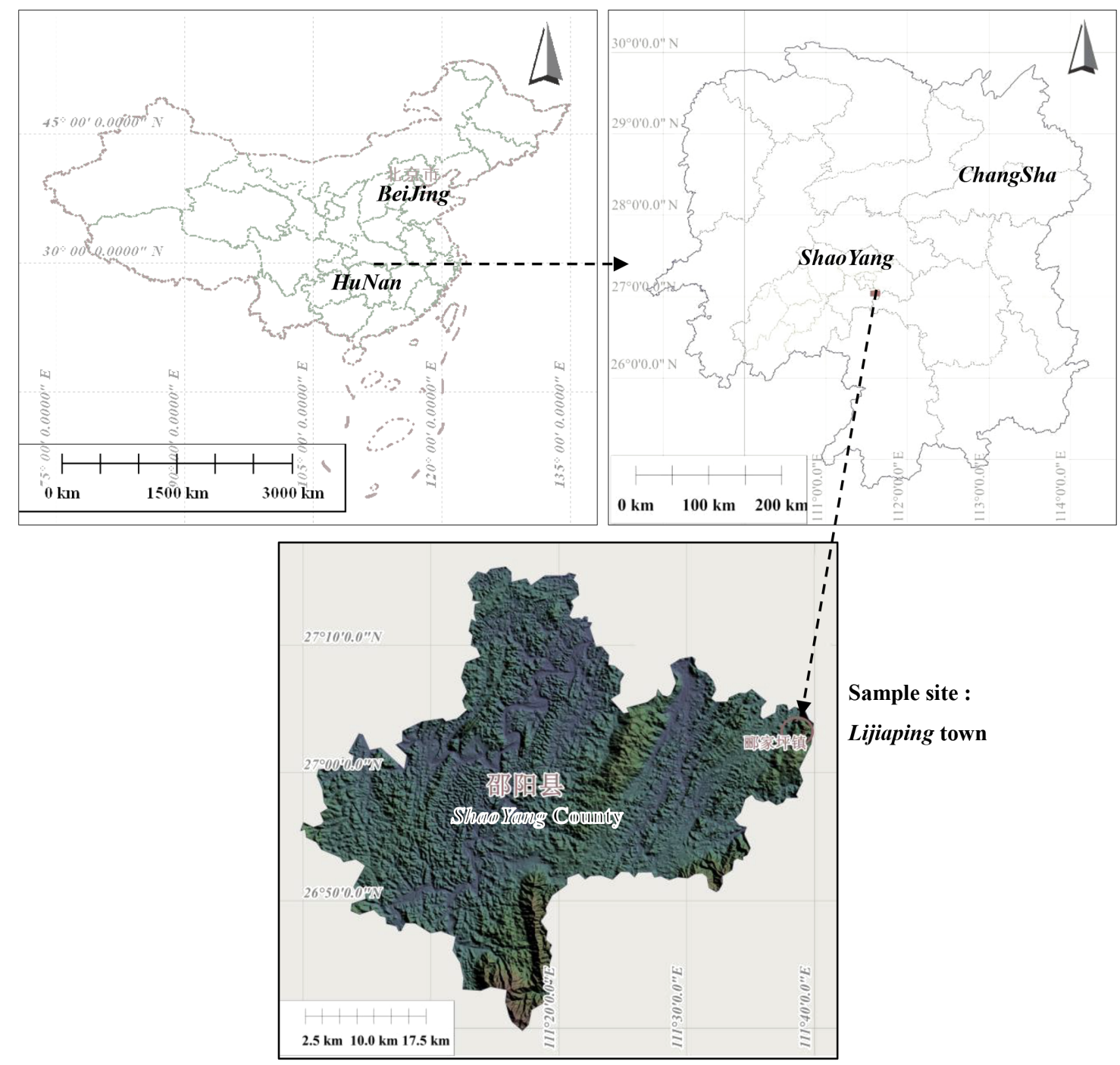

Figure 1. Geographical locations of the study sites.

Table 1. Basic description for different grades of rocky desertification sites.

\begin{tabular}{lrlrrrrrr}
\hline $\begin{array}{l}\text { Sample } \\
\text { areas }\end{array}$ & $\begin{array}{r}\text { Score of rocky } \\
\text { desertification }\end{array}$ & Aspect & $\begin{array}{r}\text { Soil } \\
\mathrm{pH}\end{array}$ & $\begin{array}{r}\text { Gradient } \\
\left({ }^{\circ}\right)\end{array}$ & $\begin{array}{r}\text { Altitude } \\
(\mathrm{m})\end{array}$ & $\begin{array}{r}\text { Bedrock } \\
\text { exposure rate }\end{array}$ & $\begin{array}{r}\text { Vegetation } \\
\text { coverage }\end{array}$ & $\begin{array}{l}\text { Disturbance } \\
\text { regimes }\end{array}$ \\
\hline LRD & $34(\leq 45)$ & South & 5.56 & $20^{\circ}$ & 500 & $35 \%$ & $80 \%$ & $\begin{array}{l}\text { Slight human disturbance, } \\
\text { rarely grazed }\end{array}$ \\
\hline MRD & $48(46-60)$ & Northeast & 5.57 & $18^{\circ}$ & 500 & $57 \%$ & $75 \%$ & $\begin{array}{l}\text { Abandoned farmland, } \\
\text { no disturbance after } \\
\text { abandoning cultivation }\end{array}$ \\
\hline IRD & $67(61-75)$ & Southwest & 5.59 & $17^{\circ}$ & 480 & $73 \%$ & $40 \%$ & $\begin{array}{l}\text { Slight human disturbance, } \\
\text { rarely grazed }\end{array}$ \\
\hline
\end{tabular}

LRD: light rocky desertification; MRD: moderate rocky desertification; IRD: intense rocky desertification. 
We carried out a two-way analysis of variance (ANOVA) for both species and soil for 17 widespread plants to determine differences in plant $\mathrm{Ca}$ content. A one-way ANOVA was used to analyze the $\mathrm{Ca}$ content of soil and plants between different grades of rocky desertification. Pearson correlation analysis $(\alpha=0.05)$ was used to analyze the correlation between plant $\mathrm{Ca}$ and soil ECa content. All statistical analyses were performed using R 3.3.3 (R Core Team, 2017).

\section{Results}

\subsection{The properties of soil in different grades of rocky desertification}

The mean TCa content in soil was $2.40 \mathrm{~g} \mathrm{~kg}^{-1}$ (range: 0.10 $8.09 \mathrm{~g} \mathrm{~kg}^{-1}$ ) while the mean ECa content was $1.46 \mathrm{~g} \mathrm{~kg}^{-1}$ (range: $0.02-3.92 \mathrm{~g} \mathrm{~kg}^{-1}$ ). Differences between different sample locations (non-rocky side and rocky side) were significant $(p<0.05)$ for both TCa and ECa. The mean soil TCa and ECa content were found to be highest in areas of IRD, followed by MRD, then LRD. However, only the mean soil ECa content showed significant differences $(p<0.05)$ across the three different grades of rocky desertification. Regarding the availability of $\mathrm{Ca}$, the average availability of $\mathrm{Ca}$ was $59.75 \%$, with the MRD showing the highest value at $72.55 \%$, followed by IRD at $58.98 \%$, and LRD showing the lowest value at $47.72 \%$ (Table 2).

\subsection{The Ca content of plants}

\subsubsection{The Ca content of plants in different grades of rocky desertification areas}

A total of 41 plant species were collected from the three different grades of rocky desertification. The mean $\mathrm{Ca}$ content of the aboveground parts of these plants was $19.67 \mathrm{~g} \mathrm{~kg}^{-1}$ (range: $4.34-40.24 \mathrm{~g} \mathrm{~kg}^{-1}$ ). The mean Ca content of the belowground parts was $10.79 \mathrm{~g} \mathrm{~kg}^{-1}$ (range: $4.41-$ $33.62 \mathrm{~g} \mathrm{~kg}^{-1}$ ). The $\mathrm{Ca}$ content of the aboveground parts was significantly higher than that of the belowground parts $(p<0.05)$ throughout the same grades of rocky desertification, but the $\mathrm{Ca}$ content of aboveground and belowground parts showed no significant differences $(p>0.05)$ among the three different grades of rocky desertification (Fig. 2).

\subsubsection{Ca content in different plant functional groups}

The 41 plant species were identified and divided into different functional groups in the 36 small quadrats. The $\mathrm{Ca}$ content of the aboveground parts was significantly higher than that of the belowground parts in each group $(p<0.05)$. Nitrogen-fixing plants $\left(22.48 \mathrm{~g} \mathrm{~kg}^{-1}\right)$ showed a slightly higher $\mathrm{Ca}$ content in the aboveground parts compared to non-nitrogen-fixing plants (19.39 $\left.\mathrm{g} \mathrm{kg}^{-1} ; p>0.05\right)$, although $\mathrm{Ca}$ content in the belowground parts of nitrogen-fixing

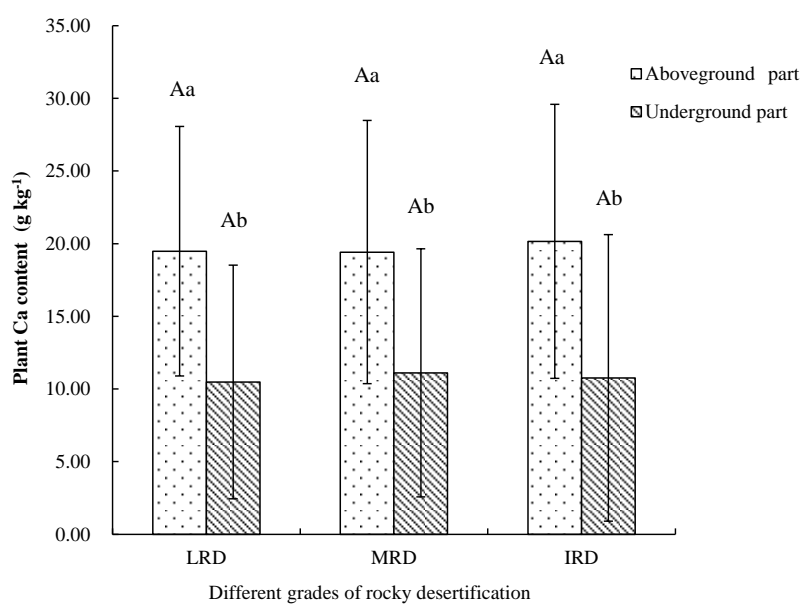

Figure 2. Characteristics of plant $\mathrm{Ca}$ content in different grades of rocky desertification. LRD: light rocky desertification; MRD: moderate rocky desertification; IRD: intense rocky desertification. Different lowercase letters represent significant differences in the $\mathrm{Ca}$ content between the aboveground and belowground parts of the plants in the same grade of rocky desertification; different uppercase letters represent significant differences in the Ca content of the plants among the different grades of rocky desertification $(p<0.05)$.

plants $\left(6.76 \mathrm{~g} \mathrm{~kg}^{-1}\right)$ was lower than that of non-nitrogenfixing plants $\left(11.12 \mathrm{~g} \mathrm{~kg}^{-1} ; p>0.05\right)$. For $\mathrm{C} 3$ plants, $\mathrm{Ca}$ content in the aboveground and belowground parts were 21.08 and $13.18 \mathrm{~g} \mathrm{~kg}^{-1}$, respectively, and were both significantly higher than that of $\mathrm{C} 4$ plants (aboveground: $15.68 \mathrm{~g} \mathrm{~kg}^{-1}$; belowground: $\left.6.42 \mathrm{~g} \mathrm{~kg}^{-1} ; p<0.05\right)$. In the life form functional groups, shrubs showed a significantly higher $\mathrm{Ca}$ content than herbs in both aboveground and belowground parts $(p<0.05)$, although there were no significant differences $(p>0.05)$ between deciduous and evergreen shrubs $(p>0.05)$. There was also no statistical difference in this respect between annual herbs and perennial herbs $(p>0.05)$. The Ca content of dicotyledons in aboveground and belowground parts were 21.39 and $12.19 \mathrm{~g} \mathrm{~kg}^{-1}$, respectively, and were significantly higher than that of monocotyledons $(9.63$ and $4.79 \mathrm{~g} \mathrm{~kg}^{-1}$, respectively; $p<0.05$ ) (Fig. 3). Monocotyledons and dicotyledons showed no significant differences in the plant $\mathrm{Ca}$ content of the aboveground parts among the different grades of rocky desertification; this was also true for the plant $\mathrm{Ca}$ content of the belowground parts. The Ca content of dicotyledons was significantly higher than that of monocotyledons in both aboveground and belowground parts throughout the three grades of rocky desertification $(p<0.05)$ (Fig. 4).

Within the total of 41 common plant species, 17 plant species were found in each sample plot and were widespread throughout the southwestern rocky desertification areas of Hunan. The important values (IV) of these 17 species were calculated (Table 3). Data showed that the differences in $\mathrm{Ca}$ content in the aboveground parts of the 17 plant species were 
Table 2. Soil TCa and ECa content from different grades of rocky desertification.

\begin{tabular}{llrrr}
\hline Ca typical $\left(\mathrm{g} \mathrm{kg}^{-1}\right)$ & Sample location & LRD & MRD & IRD \\
\hline $\mathrm{TCa}$ & Non-rocky side & $1.19 \pm 0.45 \mathrm{Aa}$ & $2.33 \pm 0.53 \mathrm{Ba}$ & $2.62 \pm 0.97 \mathrm{Ba}$ \\
& Rocky side & $1.68 \pm 0.53 \mathrm{Ab}$ & $2.97 \pm 0.29 \mathrm{Bb}$ & $5.66 \pm 1.37 \mathrm{Cb}$ \\
& Average & $1.31 \pm 0.51 \mathrm{~A}$ & $2.53 \pm 0.56 \mathrm{~B}$ & $3.38 \pm 1.71 \mathrm{~B}$ \\
\hline $\mathrm{ECa}$ & Non-rocky side & $0.51 \pm 0.26 \mathrm{Aa}$ & $1.68 \pm 0.37 \mathrm{Ba}$ & $1.63 \pm 0.88 \mathrm{Ba}$ \\
& Rocky side & $0.97 \pm 0.39 \mathrm{Ab}$ & $2.20 \pm 0.39 \mathrm{Bb}$ & $3.09 \pm 0.58 \mathrm{Cb}$ \\
& Average & $0.63 \pm 0.36 \mathrm{~A}$ & $1.83 \pm 0.44 \mathrm{~B}$ & $2.00 \pm 1.03 \mathrm{C}$ \\
\hline $\mathrm{Ca}$ effectiveness & ECa / TCa $(\%)$ & 47.72 & 72.55 & 58.98 \\
\hline
\end{tabular}

The data represent mean \pm standard deviation. Different lowercase letters in each column represent significant differences in different sample points within the same grade of rocky desertification. Different uppercase letters in each row represent significant differences between different grades of rocky desertification $(p<0.05)$.

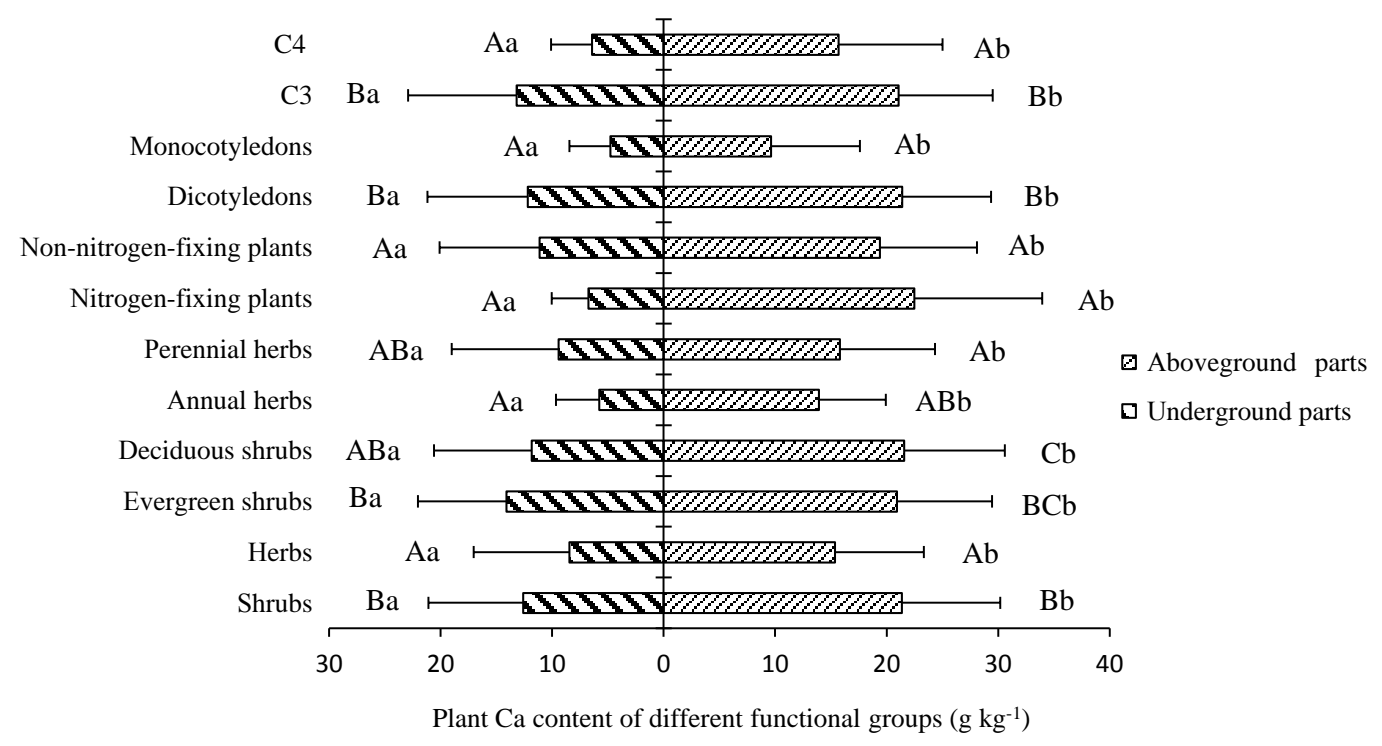

Figure 3. Ca content in the aboveground and belowground parts of plants in different functional groups. Different lowercase letters represent significant differences between the Ca content of the aboveground and belowground parts for the same functional groups $(p<0.05)$; different uppercase letters represent significant differences among different functional groups $(p<0.05)$.

highly significant $(p<0.01)$ among species, although these differences were not related to grades of rocky desertification. Differences in the Ca content of the belowground parts were highly significant not only among species, but throughout all the grades of rocky desertification $(p<0.01)$.

\subsection{Correlation between plant Ca content and soil ECa content}

Of these 17 plant species, the Ca content in the aboveground and belowground parts of Sanguisorba officinalis had a significant positive correlation $(p<0.01)$ with soil ECa content. The Ca content in the belowground parts of Dendranthema indicum $(p<0.05)$ and Castanea henryi $(p<0.01)$ also showed a significant positive correlation $(p<0.01)$ with soil ECa content. The Ca content in the aboveground parts of Themeda japonica also showed a significant positive cor- relation $(p<0.01)$ with soil ECa content. With regard to the other plants, the $\mathrm{Ca}$ content in the aboveground and belowground parts did not show a significant positive correlation $(p>0.05)$ with soil ECa content (Table 4).

\subsection{Capacity of plants adapting to high Ca soil environments}

The above 17 plants were dominant and common species in rocky desertification areas. These species appear to have a strong capacity to adapt to high-Ca environments in rocky desertification areas. The aboveground parts of plants play an important role in physiological metabolism, and their elemental content reflects the physiological and ecological characteristics of the plant.

The Ca-indifferent plants included Sanguisorba officinalis, Castanea henryi, Dendranthema indicum, and 
Table 3. The main species of plant identified during this study and their important value in different grades of rocky desertification.

\begin{tabular}{|c|c|c|c|c|}
\hline \multirow[t]{2}{*}{ Vegetable layer } & \multirow[t]{2}{*}{ Species } & \multicolumn{3}{|c|}{ Important value } \\
\hline & & LRD \% & $\mathrm{MRD} \%$ & IRD \% \\
\hline \multirow[t]{17}{*}{ Shrubs } & Abelia chinensis & 18.56 & 6.91 & 21.65 \\
\hline & Castanea henryi & 22.33 & 1.35 & 5.32 \\
\hline & Indigofera tinctoria & 5.10 & 16.64 & 4.30 \\
\hline & Pyracantha fortuneana & 5.26 & 4.83 & 1.63 \\
\hline & Loropetalum chinense & - & 1.00 & 10.45 \\
\hline & Serissa japonica & 4.13 & 5.80 & 7.45 \\
\hline & Vitex negundo & 4.85 & 11.38 & 19.07 \\
\hline & Rhus chinensis & 0.84 & 7.11 & 2.24 \\
\hline & Smilax china & - & 1.23 & 1.02 \\
\hline & Glochidion puberum & 11.36 & 4.81 & 4.19 \\
\hline & Ilex chinensis & 2.25 & - & - \\
\hline & Ilex cornuta & - & - & 1.32 \\
\hline & Elaeagnus pungens & - & 1.70 & - \\
\hline & Lespedeza bicolor & 3.01 & 0.58 & - \\
\hline & Symplocos chinensis & 2.07 & - & 1.57 \\
\hline & Broussonetia kaempferi & - & 0.79 & - \\
\hline & Populus adenopoda & 1.06 & - & - \\
\hline \multirow[t]{11}{*}{ Herbs } & Miscanthus sinensis & 36.54 & 5.82 & 36.36 \\
\hline & Artemisia carvifolia & 17.38 & 9.04 & 14.02 \\
\hline & Sanguisorba officinalis & 1.41 & 1.01 & 2.14 \\
\hline & Themeda japonica & 1.85 & 18.23 & 5.03 \\
\hline & Dendranthema indicum & 3.82 & 16.94 & 6.55 \\
\hline & Digitaria sanguinalis & 6.83 & 3.95 & 10.57 \\
\hline & Aster baccharoides & 2.40 & - & 4.30 \\
\hline & Imperata cylindrica & - & 3.30 & - \\
\hline & Salvia plebeia & - & - & 0.81 \\
\hline & Patrinia scabiosaefolia & 0.29 & - & - \\
\hline & Sonchus arvensis & - & - & 0.51 \\
\hline
\end{tabular}

“-" indicates that the important value of these species is less than 1.

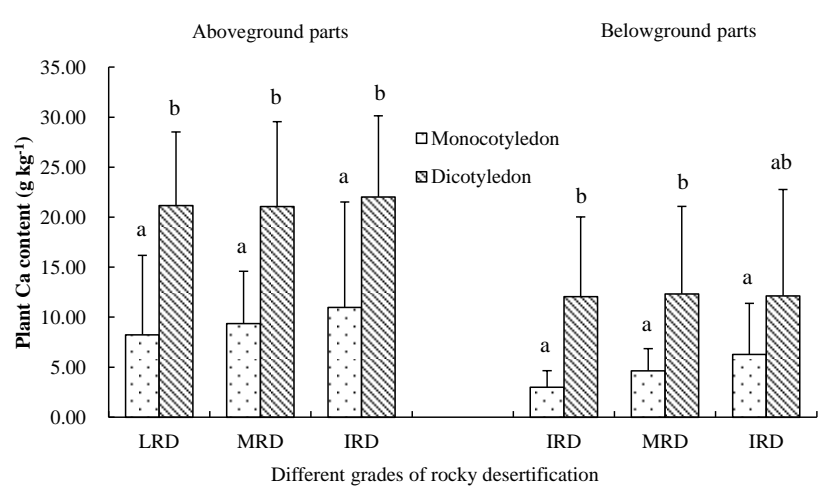

Figure 4. Ca content in the aboveground and belowground parts of different plant types from three different rocky desertification sample areas. LRD: light rocky desertification; MRD: moderate rocky desertification; IRD: intense rocky desertification. Values with the same letters were not significantly different $(p>0.05)$.
Themeda japonica. For these plants, there was a significant positive correlation between $\mathrm{Ca}$ content in the aboveground or belowground parts and the soil ECa content. These plants did not exercise a strict control over the absorption and transport of $\mathrm{Ca}$ and may be insensitive to changes in their own $\mathrm{Ca}$ content. Moreover, their growth was less affected by soil Ca content. As for the other plants, the relationship between $\mathrm{Ca}$ content in the aboveground and belowground parts and soil ECa content did not show a positive correlation. These plants were then divided into high-Ca plants and low-Ca plants, based on the differences in $\mathrm{Ca}$ content in the aboveground parts of these plants. High-Ca plants included Pyracantha fortuneana, Rhus chinensis, Loropetalum chinense, Serissa japonica, Glochidion puberum, Indigofera tinctoria, and Aster baccharoides. The aboveground parts of these plants could maintain a high $\mathrm{Ca}$ content (more than $19 \mathrm{~g} \mathrm{~kg}^{-1}$ ) under conditions of varying ECa content in the soil. Low-Ca plants included Abelia chinensis, Vitex negundo, Smilax china, Miscanthus sinensis, Artemisia carvifolia, and Digitaria sanguinalis. The aboveground parts 
Table 4. Correlations between the Ca content of 17 plant species and the soil ECa content of different rocky desertification areas.

\begin{tabular}{lrrrrrr}
\hline \multirow{2}{*}{ Species } & \multicolumn{2}{c}{ Ca content in aboveground parts } & \multicolumn{2}{c}{ Ca content in belowground parts } \\
\cline { 2 - 7 } & $\begin{array}{r}\text { Range } \\
\left(\mathrm{g} \mathrm{kg}^{-1}\right)\end{array}$ & $\begin{array}{r}\text { Mean } \pm \mathrm{SE} \\
\left(\mathrm{g} \mathrm{kg}^{-1}\right)\end{array}$ & $\begin{array}{r}\text { Correlation } \\
\text { coefficient }\end{array}$ & $\begin{array}{r}\text { Range } \\
\left(\mathrm{g} \mathrm{kg}^{-1}\right)\end{array}$ & $\begin{array}{r}\text { Mean } \pm \mathrm{SE} \\
\left(\mathrm{g} \mathrm{kg}^{-1}\right)\end{array}$ & $\begin{array}{r}\text { Correlation } \\
\text { coefficient }\end{array}$ \\
\hline Smilax china & $5.77-36.35$ & $18.5 \pm 12.24$ & 0.302 & $3.11-8.61$ & $5.89 \pm 2.75$ & 0.931 \\
Aster baccharoides & $16.16-24.03$ & $20.00 \pm 3.60$ & 0.418 & $6.20-12.02$ & $8.91 \pm 2.58$ & 0.315 \\
Vitex negundo & $5.53-26.31$ & $18.03 \pm 7.44$ & 0.198 & $2.83-8.17$ & $5.59 \pm 2.02$ & -0.116 \\
Sanguisorba officinalis & $17.68-27.77$ & $24.01 \pm 4.47$ & $0.995 * *$ & $13.41-40.14$ & $32.25 \pm 12.71$ & $0.996 * *$ \\
Themeda japonica & $2.15-9.23$ & $5.51 \pm 2.45$ & $0.963 * *$ & $0.42-7.91$ & $3.88 \pm 2.70$ & 0.488 \\
Pyracantha fortuneana & $9.16-29.84$ & $19.61 \pm 8.46$ & 0.240 & $17.08-31.86$ & $21.43 \pm 7.02$ & -0.189 \\
Loropetalum chinense & $10.33-33.44$ & $27.25 \pm 7.29$ & -0.203 & $13.62-27.69$ & $19.69 \pm 7.09$ & 0.542 \\
Serissa japonica & $9.69-33.66$ & $23.26 \pm 9.90$ & -0.027 & $4.27-20.51$ & $12.01 \pm 7.81$ & 0.838 \\
Indigofera tinctoria & $10.18-40.24$ & $24.17 \pm 11.49$ & 0.215 & $3.39-9.83$ & $5.98 \pm 2.33$ & -0.289 \\
Digitaria sanguinalis & $4.75-9.80$ & $6.67 \pm 2.73$ & 0.257 & $1.36-5.33$ & $3.37 \pm 1.98$ & -0.915 \\
Abelia chinensis & $5.07-29.64$ & $18.08 \pm 10.12$ & -0.163 & $0.87-7.12$ & $4.10 \pm 2.16$ & 0.070 \\
Artemisia carvifolia & $15.34-19.39$ & $17.37 \pm 1.42$ & 0.400 & $6.39-14.07$ & $9.18 \pm 3.07$ & 0.028 \\
Glochidion puberum & $11.13-26.99$ & $20.49 \pm 7.04$ & 0.357 & $5.33-13.64$ & $10.45 \pm 4.48$ & 0.775 \\
Miscanthus sinensis & $4.34-7.60$ & $5.61 \pm 1.44$ & 0.000 & $2.88-13.10$ & $5.82 \pm 4.87$ & 0.118 \\
Rhus chinensis & $10.52-28.16$ & $19.93 \pm 6.43$ & 0.076 & $8.92-20.38$ & $14.13 \pm 4.13$ & 0.336 \\
Dendranthema indicum & $20.97-24.96$ & $22.54 \pm 1.86$ & 0.666 & $2.97-7.39$ & $5.39 \pm 1.70$ & $0.877 *$ \\
Castanea henryi & $12.99-38.74$ & $22.4 \pm 8.17$ & 0.151 & $20.52-31.37$ & $25.28 \pm 3.92$ & $0.963 * *$ \\
\hline
\end{tabular}

Coefficients are significant at $p<0.05(*)$ and $<0.01(* *)$.

Table 5. Adaptation of plants to high Ca environments in rocky desertification areas.

\begin{tabular}{lll}
\hline $\begin{array}{l}\text { Types of } \\
\text { adaptation }\end{array}$ & Species & $\begin{array}{l}\text { Characteristics of Ca content in } \\
\text { plants }\end{array}$ \\
\hline $\begin{array}{l}\text { Ca-indifferent } \\
\text { plants }\end{array}$ & $\begin{array}{l}\text { Sanguisorba officinalis } \\
\text { Castanea henryi } \\
\text { Dendranthema indicum } \\
\text { Themeda japonica }\end{array}$ & $\begin{array}{l}\text { There is significant positive corre- } \\
\text { lation between the Ca content in the } \\
\text { aboveground/belowground parts of } \\
\text { plants and the soil ECa content. The } \\
\text { coefficient of variation for Ca con- } \\
\text { tent in plants has a wide range. }\end{array}$ \\
\end{tabular}

\begin{tabular}{|c|c|c|c|}
\hline $\begin{array}{l}\text { High-Ca } \\
\text { plants }\end{array}$ & $\begin{array}{l}\text { Loropetalum chinense } \\
\text { Serissa japonica } \\
\text { Indigofera tinctoria } \\
\text { Glochidion puberum } \\
\text { Aster baccharoides } \\
\text { Pyracantha fortuneana } \\
\text { Rhus chinensis }\end{array}$ & $\begin{array}{l}\text { There is no significant positive cor- } \\
\text { relation between the Ca content in } \\
\text { the aboveground parts of plants and } \\
\text { the soil ECa content. The above- } \\
\text { ground part has a high level of Ca } \\
\text { content and the coefficient of varia- } \\
\text { tion falls within a narrow range. }\end{array}$ & $\begin{array}{l}\text { Plants maintain high Ca content by } \\
\text { enhancing Ca uptake and transport- } \\
\text { ing it from belowground to above- } \\
\text { ground parts. High Ca is needed or } \\
\text { tolerated in these plants. }\end{array}$ \\
\hline $\begin{array}{l}\text { Low-Ca } \\
\text { plants }\end{array}$ & $\begin{array}{l}\text { Vitex negundo } \\
\text { Abelia chinensis } \\
\text { Smilax china } \\
\text { Miscanthus sinensis } \\
\text { Artemisia carvifolia } \\
\text { Digitaria sanguinalis }\end{array}$ & $\begin{array}{l}\text { There is no significant positive cor- } \\
\text { relation between the Ca content in } \\
\text { the aboveground parts of plants and } \\
\text { the soil ECa content. The above- } \\
\text { ground part has a low level of Ca } \\
\text { content and the coefficient of varia- } \\
\text { tion falls within a narrow range. }\end{array}$ & $\begin{array}{l}\text { Plants maintain low } \mathrm{Ca} \text { content in } \\
\text { the aboveground parts by reducing } \\
\text { Ca uptake and transporting it from } \\
\text { belowground to aboveground parts. }\end{array}$ \\
\hline
\end{tabular}


of these plants could maintain a low $\mathrm{Ca}$ content (less than $19 \mathrm{~g} \mathrm{~kg}^{-1}$ ) under conditions of varying $\mathrm{ECa}$ content in the soil (Table 5).

\section{Discussion}

\subsection{Dynamics of $\mathrm{Ca}$ content in plants and soil}

The soil Ca content increased with the grade of rocky desertification, which indicates that soil Ca content was affected by the grade of rocky desertification. The mean soil ECa content was $1.46 \mathrm{~g} \mathrm{~kg}^{-1}$ in these three different grades of rocky desertification, which was lower than the average ECa content in tobacco-planting soil in Hunan Province ( $3.548 \mathrm{~g} \mathrm{~kg}^{-1}$ ) (Xu et al., 2007). The average ECa content in IRD areas was $3.09 \mathrm{~g} \mathrm{~kg}^{-1}$, which was several times higher than the previously reported $\mathrm{ECa}$ for non-limestone regions in China (Xu et al., 2007). The range of soil ECa content in the study area is from (LRD) 0.02 to (IRD) $3.92 \mathrm{~g} \mathrm{~kg}^{-1}$, with the maximum and minimum being lower than that of soil on Barro Colorado Island, Panama by Messmer et al. (2014). Tanikawa et al. (2017) revealed that concentrations of TCa and ECa were also low at the deeper horizons in low-acid buffering capacity $(\mathrm{ABC})$ soils, and that differences in both soil organic layer depth and soil chemistry could be a reason for the difference in $\mathrm{Ca}$ accumulation in low- and high-ABC stands. Our research showed that mean soil TCa and ECa contents were the lowest in LRD areas, and that the difference in soil $\mathrm{TCa}$ and ECa may be caused by bedrock exposure rate (the main chemical composition of the bedrock: $\mathrm{CaCO}_{3}$ ) (Ji et al., 2009).

There were no significant differences in plant $\mathrm{Ca}$ content among the different grades of rocky desertification for either the aboveground or belowground parts of the plants $(p>0.05)$, indicating that the grade of rocky desertification had no obvious effect on the Ca content of the different plants sections. However, the average $\mathrm{Ca}$ content of the aboveground parts of plants $\left(19.67 \mathrm{~g} \mathrm{~kg}^{-1}\right)$ was lower than that of Hunan flue-cured tobacco $\left(21.93 \mathrm{~g} \mathrm{~kg}^{-1}\right.$ ) (Xu et al., 2007). The maximum and minimum Ca content of plant aboveground parts were 41.79 and $2.15 \mathrm{~g} \mathrm{~kg}^{-1}$ respectively, and the maximum and minimum $\mathrm{Ca}$ content of plant belowground parts were 40.14 and $0.42 \mathrm{~g} \mathrm{~kg}^{-1}$ respectively. The maximum Ca content of plants $\left(41.79 \mathrm{~g} \mathrm{~kg}^{-1}\right)$ was found in the leaves, which was lower than the $\mathrm{Ca}$ content of calcareous plant leaves with the maximum value of $85.13 \mathrm{~g} \mathrm{~kg}^{-1} \mathrm{de}-$ tected by Luo et al. (2014). For most plants, the Ca content in the aboveground part was higher than in the belowground part, but for a few plants the Ca content in the aboveground part was lower than in the belowground part (such as Sanguisorba officinalis, Pyracantha fortuneana, and Castanea henryi), which was consistent with the findings of Wang et al. (2014).

\subsection{Correlation between plant Ca content and soil ECa content}

Our results showed that most plants had no correlation relationship between soil ECa and plant $\mathrm{Ca}$ except for several plants (Sanguisorba officinalis, Dendranthema indicum, Castanea henryi, and Themeda japonica) which showed a positive correlation between soil $\mathrm{ECa}$ and plant $\mathrm{Ca}$ content (Table 4). Some studies showed that Ca-rich soils caused cells to absorb more $\mathrm{Ca}$ than the cells themselves require (White and Broadley, 2003). Additionally, soil ECa content and leaf $\mathrm{Ca}$ content (Flue-cured Tobacco) had a significant positive correlation in a pot experiment (Zou et al., 2010). The difference between the findings of these studies and ours may be caused by species factors. The correlation between plant $\mathrm{Ca}$ content and soil $\mathrm{ECa}$ content reflects the extent to which soil $\mathrm{Ca}$ content influences plant $\mathrm{Ca}$ content, and may also reflect how different plants respond to differences in soil ECa content (Ji et al., 2009). The Ca content of Sanguisorba officinalis in the aboveground and belowground parts had a significant positive correlation $(p<0.01)$ with soil ECa content, which indicates that Sanguisorba officinalis was greatly affected by soil ECa content. The Ca content of Dendranthema indicum $(p<0.05)$ and Castanea henryi $(p<0.01)$ in the belowground parts also showed a significant positive correlation $(p<0.01)$ with soil ECa content, indicating that the belowground parts of these species were also markedly affected by soil ECa content. The Ca content of Themeda japonica in the aboveground parts showed a significant positive correlation $(p<0.01)$ with soil ECa content, which indicates that the aboveground parts of Themeda japonica were also greatly affected by soil ECa content.

A two-way ANOVA of species and soil showed that the $\mathrm{Ca}$ content of the aboveground parts of the 17 plant species was mainly affected by species factors, while the Ca content of the belowground parts was affected by both species factors and the grade of rocky desertification. This finding is supported by data reported by Ji et al. (2009). The Ca content in the aboveground parts of nitrogen-fixing plants was significantly higher than that of the belowground parts, and this result indicates that nitrogen-fixing plants were the most efficient in Ca upward transport. In contrast, Ji et al. (2009) found that dicotyledons were the most efficient in the upward transport of $\mathrm{Ca}$. However, they used only three types of plants (pteridophytes, dicotyledons, and monocotyledons) omitting nitrogen-fixing plants in their study. We found significant differences $(p<0.01)$ between the aboveground and belowground parts in the $\mathrm{Ca}$ content of monocotyledons in our study. However, Ji et al. (2009) revealed that there were no significant differences between the aboveground and belowground parts in the $\mathrm{Ca}$ content of monocotyledons. The main reason for this difference may be the different species. In addition, the $\mathrm{Ca}$ content of monocotyledons was lower than that reported for monocotyledons by Ji et al. (2009), 
highlighting the large difference in ability to absorb soil $\mathrm{Ca}$ among monocotyledon species.

\subsection{High Ca adaptation of plants}

The different plant functional groups revealed differences in Ca content (Fig. 3). In some cases, even within the same plant species, there were inconsistencies in the correlations between $\mathrm{Ca}$ content in the aboveground and belowground parts and the soil ECa content. Collectively, these findings show that not all plants adapted to high Ca soil environments in the same way, but rather exhibited a variety of adaptive mechanisms.

The aboveground parts of a plant represent the main site of its physiological activity. Thus, the $\mathrm{Ca}$ content in the aboveground part reflects the Ca demand of the plant's physiological activity (Grubb and Edwards, 1982). The capacity of those plants that are able to adapt to high $\mathrm{Ca}$ soil environments can be reflected by two indicators: (i) the correlation between $\mathrm{Ca}$ content in the aboveground parts of the plants and soil ECa content; and (ii) the species differences in terms of the $\mathrm{Ca}$ content of the aboveground parts of plants. Thus, based on these two indicators, plants can be placed into the following groups: Ca-indifferent plants, high-Ca plants, and low-Ca plants (Ji et al., 2009). We used this classification method to categorize the 17 plant species that were widely distributed across our study environment, thus providing theoretical guidance for vegetation restoration in rocky desertification areas. In both high-Ca and low-Ca soil environments, the Ca-indifferent plants can survive normally, and their $\mathrm{Ca}$ content changes correspond to changes in soil ECa content. The physiological activities of high-Ca plants have a higher demand for $\mathrm{Ca}$ and may have a strong ability to absorb soil $\mathrm{Ca}$. The physiological activities of low-Ca plants have a lower demand for $\mathrm{Ca}$ and can alleviate high $\mathrm{Ca}$ stress by inhibiting the absorption of $\mathrm{Ca}$ through the root system and its upward transport.

These results are of great significance for vegetation restoration in karst areas. High-Ca plants should be preferentially selected (such as Pyracantha fortuneana, Rhus chinensis, Loropetalum chinense, and Serissa japonica), followed by Ca-indifferent plants (such as Sanguisorba officinalis, Castanea henryi, and Dendranthema indicum). LowCa plants should only be used as an alternative species to increase species diversity during the process of ecological restoration. Our findings not only have important significance for guiding solutions to the problem of rocky desertification in China, but also provide species screening ideas for ecosystem restoration in rocky desertification areas in other parts of the world. Rocky desertification is a major ecological problem in karst areas, and further research is required to solve this problem. It is necessary to further explore other nutrient elements in soil during vegetation restoration, and long-term positioning observation is crucial for understanding this issue.

\section{Conclusions}

Our results indicate that the mean soil TCa and ECa content were highest in areas of IRD, followed by MRD, then LRD. The Ca content in the aboveground parts of plants was significantly higher than that in the belowground parts of plants in the three grades of rocky desertification sites in our study. Significant differences in plant $\mathrm{Ca}$ content were found between the aboveground and belowground parts in each plant functional group. The soil ECa content had a significant effect on the $\mathrm{Ca}$ content of the belowground parts of plants but no significant effect on the $\mathrm{Ca}$ content of the aboveground parts. Ca-indifferent plants, which included Sanguisorba officinalis, Castanea henryi, Dendranthema indicum, and Themeda japonica, showed a significant positive correlation between the Ca content in the aboveground or belowground parts and the soil ECa content. High-Ca plants were Pyracantha fortuneana, Rhus chinensis, Loropetalum chinense, Serissa japonica, Glochidion puberum, Indigofera tinctoria, and Aster baccharoides. The aboveground parts of these plants were able to absorb a lot of $\mathrm{Ca}$ from soils with varying ECa content. Finally, low-Ca plants included Abelia chinensis, Vitex negundo, Smilax china, Miscanthus sinensis, Artemisia carvifolia, and Digitaria sanguinalis. The aboveground parts of low-Ca plants were able to maintain a lower Ca content from soils with varying ECa content.

Data availability. We added data sets as a supplement file.

Supplement. The supplement related to this article is available online at: https://doi.org/10.5194/bg-15-2991-2018-supplement.

Author contributions. The idea and study design was conceived by DXW, WXC; the experiments and statistical analysis were carried out by DXW, WXC, and WHF; manuscript writing was undertaken by WXC; discussion and revision was carried out by XWH, OS, LPF, CL. All authors have read and approved the content of the manuscript.

Competing interests. The authors declare that they have no conflict of interest.

Acknowledgements. This work was supported by the Forestry Science and Technology Promotion Project of the State Forestry Administration of China ([2014]52), and the Desertification (Rocky Desertification) Monitoring Project of the State Forestry Administration of China (20150618 and 20160603).

Edited by: Sébastien Fontaine

Reviewed by: two anonymous referees 


\section{References}

Batistič, O. and Kudla, J.: Analysis of calcium signaling pathways in plants, Biochim. Biophys. Acta (BBA)-General Subjects, 1820, 1283-1293, 2012.

Borer, C. H., Hamby, M. N., and Hutchinson, L. H.: Plant tolerance of a high calcium environment via foliar partitioning and sequestration, J. Arid Environ., 85, 128-131, 2012.

Bose, J., Pottosin, I. I., Shabala, S. S., Palmgren, M. G., and Shabala, S.: Calcium efflux systems in stress signaling and adaptation in plants, Front. Plant Sci., 2, 85, doi:10.3389/fpls.2011.00085, 2011.

Bowler, C. and Fluhr, R.: The role of calcium and activated oxygens as signals for controlling cross-tolerance, Trends Plant Sci., 5, 241-246, 2000.

Bressan, R. A., Hasegawa, P. M., and Pardo, J. M.: Plants use calcium to resolve salt stress, Trends Plant Sci., 3, 411-412, 1998.

China, S. F.: Technology Regulations of Vegetation Restoration in Karst Desertification Zone (LY/T 1840-2009) China Standards Press, Beijing, 2009 (in Chinese with English abstract).

Grubb, P. J. and Edwards, P. J.: Studies of mineral cycling in a montane rain forest in New Guinea. III. The distribution of mineral elements in the above-ground material, J. Ecol., 70, 623-648, 1982.

Hepler, P. K.: Calcium: a central regulator of plant growth and development, Plant Cell, 17, 2142-2155, 2005.

Hetherington, A. M. and Brownlee, C.: The generation of Ca signals in plants, Annu. Rev. Plant Biol., 55, 401-427, 2004.

Hirschi, K. D.: The calcium conundrum. Both versatile nutrient and specific signal, Plant Physiol., 136, 2438-2442, 2004.

Hong-Bo, S., Li-Ye, C., and Ming-An, S.: Calcium as a versatile plant signal transducer under soil water stress, BioEssays., 30, 634-641, 2008.

Ilarslan, H., Palmer, R. G., and Horner, H. T.: Calcium oxalate crystals in developing seeds of soybean, Ann. Bot., 88, 243-257, 2001

Ji, F. T., Li, N., and Deng, X.: Calcium contents and high calcium adaptation of plants in karst areas of China, Chinese J. Plant Ecol., 33, 926-935, 2009 (in Chinese with English abstract).

Jing, Y. R., Deng, X. W., Deng, D. H., Xiang, W. H., Wenhua, X., Fang, X., Li, Y. Q., and Zhang, S. L.: Soil properties and their correlations under different grades of rocky desertification ecosystems in Southwest Hunan, China, J. Soil Water Conserv., 30, 189-195, 2016 (in Chinese with English abstract).

Kinzel, H.: Calcium in the vacuoles and cell walls of plant tissue, Flora, 182, 99-125, 1989.

Larkindale, J. and Knight, M. R.: Protection against heat stressinduced oxidative damage in Arabidopsis involves calcium, abscisic acid, ethylene, and salicylic acid, Plant Physiol., 128, 682695, 2002

Li, Y. Q, Deng, X. W., Yi, C. Y., Deng, D. H., Huang, Z. H., Xiang, W. H., Fang, X., and Jing, Y. R.: Plant and soil nutrient characteristics in the karst shrub ecosystem of southwest Hunan, China, Chinese Journal of Applied Ecology, 27, 1015-1023, 2016 (in Chinese with English abstract)

Luo, X. Q., Wang, C. Y., Yang, H. Y., and Liao, X. R.: Studies on adaptive mechanisms of karst dominant plant species to drought and high calcium stress, Chinese Agricultural Science Bulletin, 28, 1-5, 2012 (in Chinese with English abstract).
Luo, X. Q., Wang, S. J., Zhang, G. L., Wang, C. Y., Yang, H. Y., and Liao, X. R.: Effects of calcium concentration on photosynthesis characteristics of two fern plants, Ecology and Environmental Science, 22, 258-262, 2013 (in Chinese with English abstract).

Luo, X. Q., Zhang, G. L., Du, X. L., Wang, S. J., Yang, H. Y., and Huang, T. Z.: Characteristics of element contents and ecological stoichiometry in leaves of common calcicole species in Maolan Karst Forest, Ecology and Environmental Sciences, 23, 11211129, 2014 (in Chinese with English abstract).

Marschner, H.: Marschner's mineral Nutrition of Higher Plants, Academic Press, 2011.

Messmer, T., Elsenbeer, H., and Wilcke, W.: High exchangeable calcium concentrations in soils on Barro Colorado Island, Panama, Geoderma, 217-218, 212-224, 2014.

Moore, C. A., Bowen, H. C., Scrasefield, S., Knight, M. R., and White, P. J.: The deposition of suberin lamellae determines the magnitude of cytosolic Ca elevations in root endodermal cells subjected to cooling, Plant J., 30, 457-465, 2002.

Müller, M. N., Barcelos e Ramos, J., Schulz, K. G., Riebesell, U., Kazmierczak, J., Gallo, F., Mackinder, L., Li, Y. Q., Nesterenko, P. N., Trull, T. W., and Hallegraeff, G. M.: Phytoplankton calcification as an effective mechanism to alleviate cellular calcium poisoning, Biogeosciences, 12, 6493-6501, https://doi.org/10.5194/bg-12-6493-2015, 2015.

Musetti, R. and Favali, M. A.: Cytochemical localization of calcium and X-ray microanalysis of Catharanthus roseus L. infected with phytoplasmas, Micron, 34, 387-393, 2003.

Peiter, E.: The plant vacuole: emitter and receiver of calcium signals, Cell Calcium, 50, 120-128, 2011.

Pennisi, S. V. and McConnell, D. B.: Inducible calcium sinks and preferential calcium allocation in leaf primordia of Dracaena sanderiana Hort, Sander ex MT Mast, (Dracaenaceae), HortScience, 36, 1187-1191, 2001.

Poovaiah, B. W. and Reddy, A. S.: Calcium and signal transduction in plants, CRC Crit. Rev. Plant Sci., 12, 185-211, 1993.

Qi, Q. W., Hao, Z., Tao, J. J., and Kang, M.: Diversity of calcium speciation in leaves of Primulina species (Gesneriaceae), Biodiversity Science, 21, 715-722, 2013 (in Chinese with English abstract).

R Core Team R: A language and environment for statistical computing, R Foundation for Statistical Computing, Vienna, Austria, available at: https://www.R-project.org/, 2017.

Ranjev, R., Thuleaua, P., and Schroederb, J. I.: Signal transduction and calcium channels in higher plants, Curr. Opin. Biotechnol., 4, 172-176, 1993.

Reuveni, R., Dor, G., Raviv, M., Reuveni, M., and Tuzun, S.: Systemic resistance against Sphaerotheca fuliginea in cucumber plants exposed to phosphate in hydroponics system, and its control by foliar spray of mono-potassium phosphate, Crop Prot., 19, 355-361, 2000.

Shang, Z. L., Mao, G. H., A., and Sun, D. Y.: The specificity of calcium signaling in plant cells, Plant Physiology Communications, 39, 93-100, 2003 (in Chinese with English abstract).

Sheng, M. Y., Xiong, K. N., Cui, G. Y., and Liu, Y.: Plant diversity and soil physical-chemical properties in karst rocky desertification ecosystem of Guizhou, China, Acta Ecol. Sin, 35, 434-448, 2015 (in Chinese with English abstract).

Tanikawa, T., Ito, Y., Fukushima, S., Yamashita, M., Sugiyama, A., Mizoguchi, T., Okamoto, T., and Hirano, Y.: Calcium is cycled 
tightly in Cryptomeria japonica stands on soils with low acid buffering capacity, Forest Ecol. Manage., 399, 64-73, 2017.

Volk, G. M., Lynch-Holm, V. J., Kostman, T. A., Goss, L. J., and Franceschi, V. R.: The role of druse and raphide calcium oxalate crystals in tissue calcium regulation in Pistia stratiotes L. leaves, Plant Biol., 4, 34-45, 2002.

Wang, C. M. and Yi, Y.: Physiological activity and calcium content of calciphile, ubiquists and calcifuge under nature environment, Hubei Agricultural Sciences, 53, 3840-3844, 2014 (in Chinese with English abstract).

Wang, C. Y., Wang, S. J., Rong, L., and Luo, X. Q.: Analyzing about characteristics of calcium content and mechanisms of high calcium adaptation of common pteridophyte in Maolan karst area of China, Chinese J. Plant Ecol., 35, 1061-1069, 2011 (in Chinese with English abstract).

Wang, H., Inukai, Y., and Yamauchi, A.: Root development and nutrient uptake, CRC Crit. Rev. Plant Sci., 25, 279-301, 2006.

Wang, S. J., Liu, Q. M., and Zhang, D. F.: Karst rocky desertification in southwestern China: geomorphology, landuse, impact and rehabilitation, Land Degrad. Dev., 15, 115-121, 2004.

Wang, Y. J., Yu, J. N., Chen, T., Zhang, Z. G., Hao, Y. J., Zhang, J. S., and Chen, S. Y.: Functional analysis of a putative Ca channel gene TaTPC1 from wheat, J. Exp. Bot., 56, 3051-3060, 2005.
White, P. J. and Broadley, M. R.: Calcium in plants, Ann. Bot., 92, 487-511, 2003.

Wu, W. H.: Plant Physiology, second edition, Science Press, 2008 (in Chinese with English abstract).

Xu, Z. C., Li, Y. Y., Xiao, H. Q., Li, H, W., and Liu, C. K.: The contents of ECalcium and magnesium in Hunan tobacco growing soils and their effects on tobacco quality, Acta Ecol. Sin., 27, 4425-4433, 2007 (in Chinese with English abstract).

Zeng, F. P., Peng, W. X., Song, T. Q., Wang, K. L., Wu, H. Y., Song, X. J., and Zeng, Z. X.: Changes in vegetation after 22 years' natural restoration in the Karst disturbed area in northwestern Guangxi, China, Acta Ecologica Sinica, 27, 5110-5119, 2007.

Zhang, X. Q.: Ecophysiological Characteristics of Calcicole and Calcifuge Responding to External Ca2 + Concentration, Guizhou Normal University, 2005 (in Chinese with English abstract).

Zhou, J., Huang, Y., and Mo, M.: Phylogenetic analysis on the soil bacteria distributed in karst forest, Braz. J. Microbiol., 40, 827837, 2009.

Zou, W. T. and Xiong, D. Z.: Effects of soil available calcium on some physiological metabolism of flue cured tobacco, Journal of Anhui Agricultural University, 37, 369-373, 2010 (in Chinese with English abstract). 